E-JURNAL EKONOMI DAN BISNIS UNIVERSITAS UDAYANA
Available online at https://ojs.unud.ac.id/index.php/EEB/index
Vol. 10 No. 02, February 2021, pages: 73-82
e-ISSN: 2337-3067

\title{
PENGARUH HARGA KOMODITAS PANGAN DAN BENSIN TERHADAP TINGKAT INFLASI SELAMA PEMERINTAHAN JOKOWI
}

\author{
Hary S. Sundoro ${ }^{1}$
}

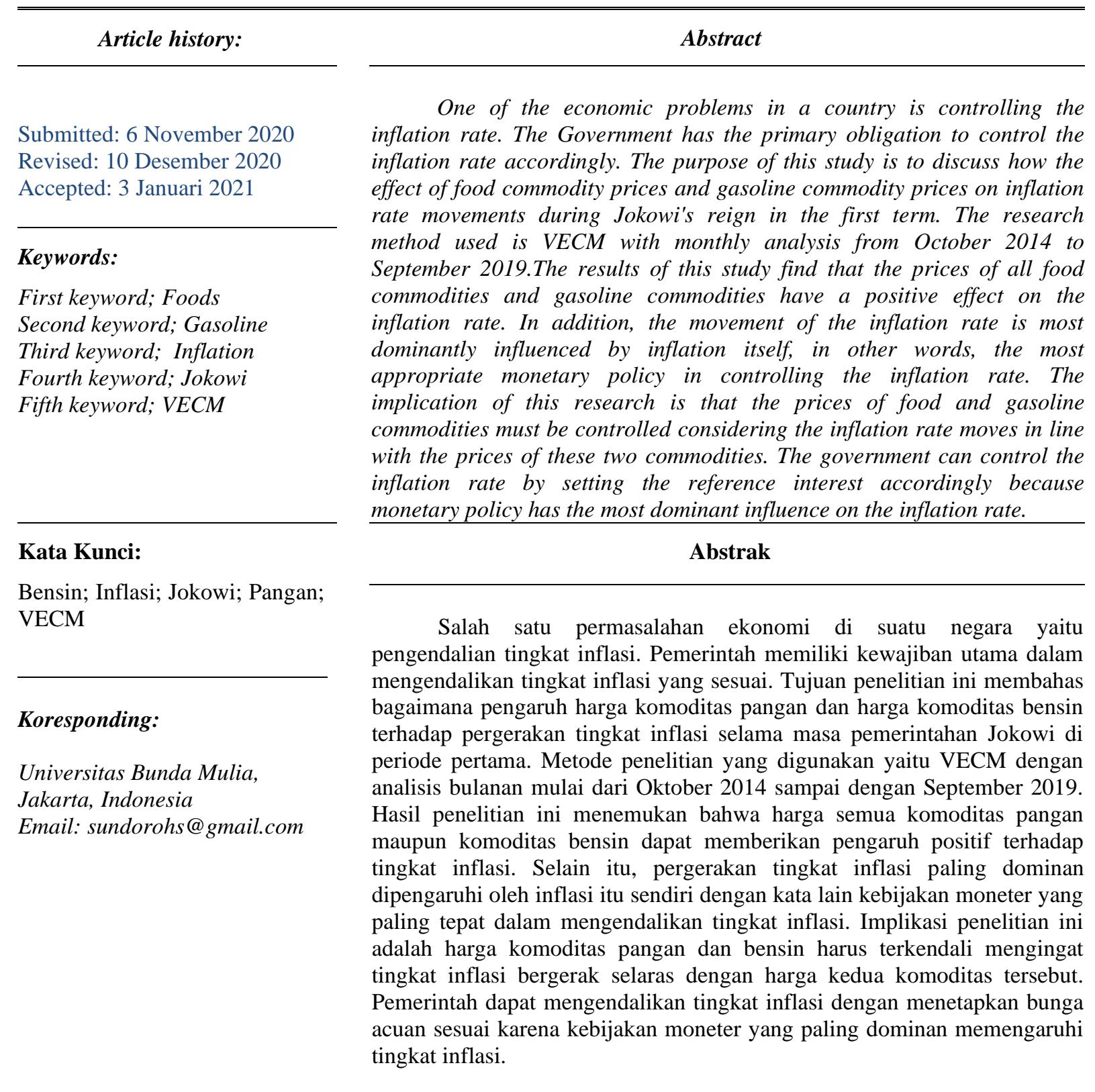




\section{PENDAHULUAN}

Kondisi perekonomian dari waktu ke waktu selalu mengalami perubahan dimana hal ini ditandai dari adanya perubahan nilai mata uang suatu negara jika dibandingkan dengan tempo-tempo sebelumnya. Ketika seseorang membelanjakan sejumlah nominal uang tertentu pada tempo sekarang, maka jumlah nominal uang tersebut belum tentu dapat memiliki nilai yang sama pada tempo selanjutnya. Alasan atau penyebab utama terjadinya penyusutan nilai mata uang di suatu negara yaitu inflasi.

Inflasi dapat memberikan dampak terhadap kebanyakan hajat hidup orang banyak antara lain seperti pada nilai mata uang, tingkat konsumsi, dan tingkat investasi (Premik \& Stanislawska, 2017). Karena inflasi telah berdampak pada banyak bidang kehidupan, oleh karena itu diperlukannya suatu analisis untuk membahas tentang inflasi. Pemahaman tentang penyebab terjadinya inflasi dapat membantu pihak-pihak terkait dalam melakukan tindakan yang sifatnya preventif terhadap kerugian yang mungkin timbul.

Dampak inflasi dapat dirasakan pula di Indonesia. Tingkat inflasi yang begitu tinggi pernah terjadi di Indonesia pada tahun 1963, 1964 dan 1965. Selain itu pada tahun 1998, Indonesia juga pernah mengalami tingkat inflasi yang cukup tinggi. Inflasi yang begitu tinggi dapat menyebabkan biaya hidup semakin tinggi semenjak terjadinya kenaikan harga-harga barang pokok. Tingkat inflasi yang begitu rendah juga akan memberikan masalah tersendiri terutama bagi negara industri yang banyak menghasilkan output.

Memasuki akhir tahun 2014, Indonesia telah memiliki seorang Presiden baru yang ke-7 yaitu Joko Widodo. Salah satu tugas utama beliau selama menjadi Presiden tentunya yaitu mengendalikan tingkat inflasi. Presiden Jokowi juga sependapat bahwa pengendalian inflasi merupakan hal yang penting karena PDB tumbuh tetapi nilainya lebih kecil daripada inflasi akan sia-sia. Apalagi kondisi ekonomi global sekarang sudah mulai tergerus oleh perang global yang dapat membuat kinerja PDB setiap negara semakin terganggu (Sundoro, 2020).

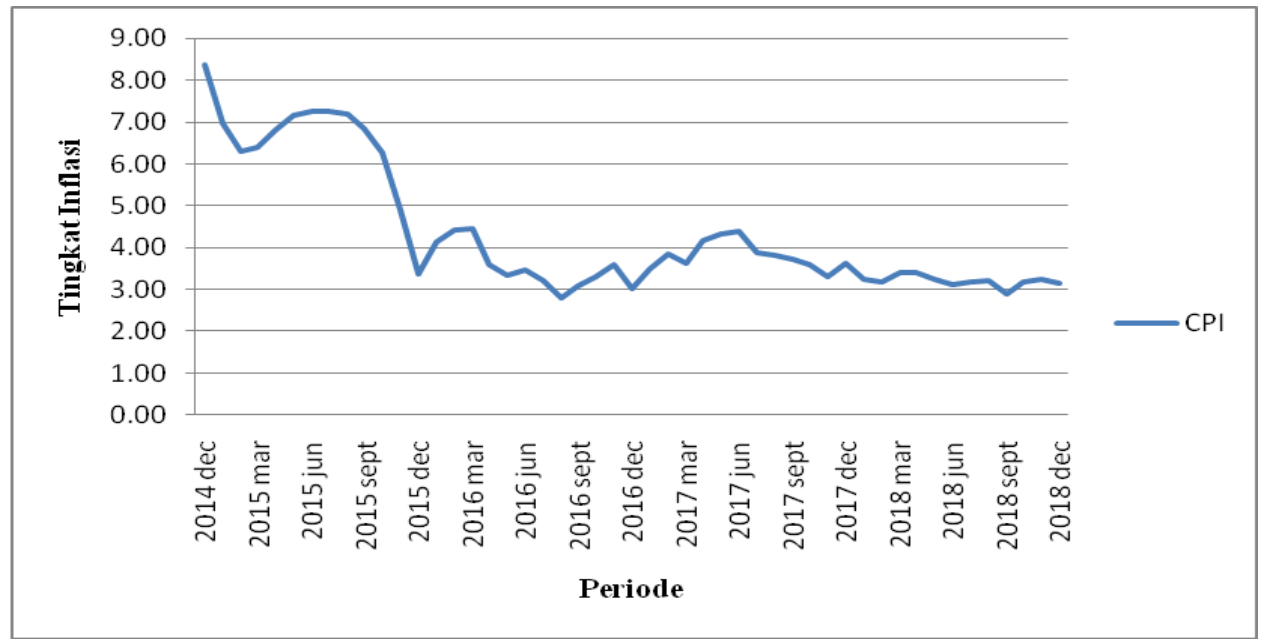

Sumber: BPS, data diolah 2020

Gambar 1.

Tingkat Inflasi Indonesia Periode Desember 2014 - Desember 2018 
Tren inflasi terus mengalami penurunan mulai dari Desember 2014 sampai dengan Desember 2018 seperti terlihat di Gambar 1. Menurut laporan BPS, sekitar 2 bulan Jokowi menjabat sebagai Presiden tingkat inflasi di Indonesia sebesar 8,36\% dan memasuki akhir tahun 2018 tingkat inflasi yaitu $3,13 \%$. Penurunan tingkat inflasi ini tentunya ada andil dari kebijakan Jokowi selama beliau menjadi Presiden. Ada beberapa kebijakan yang dapat dilakukan oleh seorang Presiden dalam mengendalikan inflasi dan salah satunya yaitu mengendalikan harga.

Kebijakan price control atau mengendalikan harga merupakan salah satu kebijakan yang dapat dilakukan dalam mengendalikan tingkat inflasi (Laguerodie \& Vergara, 2008). Perubahan harga pada komoditas pangan dapat memengaruhi tingkat inflasi seperti yang terjadi di Serbia (Radukic et al., 2015); di Amerika Serikat (Capehart \& Richardson, 2008) dan di Indonesia (Kurniawan, 2014). Harga pada komoditas pangan dianggap penting dalam memengaruhi inflasi karena dengan semakin mahalnya harga maka dapat menciptakan inflasi.

Berdasarkan Surat Keputusan Menteri Perdagangan dan Perindustrian No. 115/MPP/KEP/2/1998 yang dimasukkan sebagai barang kebutuhan pokok adalah beras, gula pasir, minyak goreng, mentega, daging sapi, daging ayam, telur ayam, susu, jagung, minyak tanah, cabai dan garam beryodium. Dengan demikian jika adanya perubahan harga pada komoditas-komoditas tersebut, maka dapat memungkinkan terjadinya inflasi.

Beberapa penelitian sebelumnya telah menemukan bahwa perubahan harga komoditas seperti beras, cabai merah dan daging ayam dapat menyebabkan inflasi. Penelitian yang dilakukan oleh Conteh et al. (2013) di Sierra Leone, oleh Nguyen et al. (2012) di Vietnam, dan Nath (2002) di Amerika Serikat menemukan bahwa harga beras dapat menjadi determinan utama terhadap tingkat inflasi. Harga cabai juga dapat menyebabkan inflasi seperti yang ditemukan oleh Zhou \& Staatz (2016). Penelitiannya yang dilakukan pada negara-negara di Afrika Barat menemukan bahwa ketersediaan cabai yang kurang dapat membuat harga cabai turut melonjak dan menyebabkan inflasi karena cabai dianggap penting pada negara-negara tersebut. Penelitian yang dilakukan di Meksiko oleh Hayes (2012), oleh Kusnadi (2017) dan Burhani et al. (2013) di Indonesia, maupun oleh Light \& Shelvin (1998) di Amerika Serikat menemukan bahwa inflasi juga dapat terjadi karena adanya pengaruh dari pergejolakan harga daging ayam.

Fluktuasi harga bensin juga dapat menyebabkan perubahan pada tingkat inflasi sesuai yang pernah ditemukan oleh beberapa penelitian sebelumnya seperti Alvarez et al (2017) di Spanyol, Celik \& Akgul (2011) di Turki, maupun Rangsamy (2017) di Afrika Selatan. Peningkatan harga bensin dapat menyebabkan kenaikan biaya input atau biaya produksi yang akhirnya dapat membuat harga-harga kebutuhan pokok turut naik. Inflasi akan dapat naik jika hal tersebut terus berdampak secara terusmenerus. Dengan demikian, fluktuasi inflasi dapat terjadi karena adanya perubahan harga-harga pangan yang dapat terdiri dari beras, cabai merah dan daging ayam ras mau pun harga bensin premium.

Penelitian ini sudah seharusnya dilakukan karena adanya beberapa alasan. Pertama, inflasi dapat memengaruhi kesejahteraan masyarakat suatu negara mau pun banyak aspek kehidupan sehingga diperlukan tolak ukur yang dapat menjelaskan penyebab inflasi. Kemudian, penelitian ini dapat menjelaskan apakah kebijakan pengendalian harga selama masa pemerintahan Jokowi dapat efektif dalam mengatasi inflasi yang terjadi. Selain itu, penelitian ini juga akan membahas seberapa besar pengaruh kebijakan pengendalian harga pada komoditas pangan dan bensin selama pemerintahan Jokowi dalam mengatasi inflasi. Kebanyakan penelitian sebelumnya hanya meneliti pengaruh dari harga pangan atau harga bensin terhadap inflasi, tetapi tidak meneliti secara bersama pengaruh dari harga komoditas pangan dan harga bensin terhadap perubahan inflasi. Penelitian ini akan mengkombinasikan kedua komoditas tersebut dalam memengaruhi pergerakan inflasi selama pemerintahan Jokowi.

Pengaruh Harga Komoditas Pangan dan Bensin Terhadap Tingkat Inflasi Selama Pemerintahan Jokowi Hary S. Sundoro 


\section{METODE PENELITIAN}

Penelitian ini akan meramalkan pergerakan tingkat inflasi nasional di Indonesia oleh karena itu variabel gayut-nya adalah tingkat inflasi. Harga komoditas pangan dan harga komoditas bensin yang akan dijadikan determinan tingkat inflasi pada penelitian ini sehingga variabel bebasnya adalah kedua komoditas tersebut. Komoditas pangan pada penelitian ini dapat terdiri dari beras, daging ayam, dan cabai merah. Sedangkan, jenis bensin yang dijadikan tolak ukur pada penelitian ini adalah bensin jenis premium.

Ada pun jenis data yang digunakan pada penelitian ini adalah data sekunder berupa data yang sudah dipublikasikan dan dapat diakses secara umum. Penelitian ini akan menggunakan metode VECM oleh karena itu data penelitian ini dalam bentuk time series (kurun waktu). Periode penelitian dimulai selama masa pemerintahan pertama Jokowi dari Oktober tahun 2014 sampai dengan September tahun 2019.

Data pada penelitian ini merupakan data sekunder yang berarti data pada variabel gayut mau pun variabel bebas di penelitian ini dapat dikumpulkan dari beberapa sumber antara lain dari website BPS dan Bank Indonesia. Tabel 1 dapat menunjukkan sumber-sumber data untuk masing-masing variabel seperti berikut ini.

Tabel 1.

Jenis Data, Simbol, Satuan, dan Sumber Data

\begin{tabular}{lllll}
\hline No. & \multicolumn{1}{c}{ Jenis Variabel } & \multicolumn{1}{c}{ Simbol } & \multicolumn{1}{c}{ Satuan } & \multicolumn{1}{c}{ Sumber Data } \\
\hline 1. & Tingkat Inflasi & INF & Persen & Bank Indonesia \\
2. & Harga Beras & GHB & Nominal & BPS \\
3. & Harga Daging Ayam & GHDA & Nominal & BPS \\
4. & Harga Cabai Merah & GHCM & Nominal & BPS \\
5. & Harga Bensin Premium & GHBP & Nominal & BPS \\
\hline
\end{tabular}

Sumber: Gabungan Beberapa Data, 2020

Seperti yang terlihat dari Tabel 1 bahwa satuan ukur pada data di semua variabel penelitian ini memiliki perbedaan. Beberapa variabel memiliki data dengan satuan persen dan nominal. Oleh karena itu untuk menyamakan satuan ukur pada data di semua variabel penelitian ini, maka satuan ukur semua data diubah ke dalam satuan persentase. Hal tersebut dilakukan untuk menyamakan dengan satuan variabel gayut di penelitian ini yaitu tingkat inflasi.

Penelitian ini menggunakan empat variabel bebas dan satu variabel gayut yang dapat dijabarkan sebagai berikut: Variabel gayut pada penelitian ini adalah tingkat inflasi nasional di Indonesia. Penelitian ini mengukur tingkat inflasi berdasarkan data yang telah dipublikasikan oleh Bank Indonesia pada website-nya. Proksi pada inflasi dalam bentuk persentase. Data inflasi diumumkan pada website Bank Indonesia di setiap bulan. Dari pernyataan tersebut, inflasi bulanan dari Oktober 2014 sampai dengan September 2019 dapat diukur dengan melihat data dari website Bank Indonesia.

Penelitian ini mengukur harga beras dengan berpedoman kepada laporan data sosial dan ekonomi yang dibuat oleh BPS. Dari pernyataan tersebut, harga beras bulanan dari Oktober 2014 sampai dengan September 2019 dapat diukur dengan melihat dari laporan data sosial dan ekonomi yang 
diterbitkan oleh BPS. Data harga komoditas beras akan disamakan proksinya dengan satuan pada tingkat inflasi yaitu dalam persentase, oleh karena itu data harga komoditas beras akan dirubah ke dalam rumus sebagai berikut:

Harga beras bulan sekarang - harga beras bulan sebelumnya x 100\%

Harga beras bulan sebelumnya

Harga daging ayam bulanan dari Oktober 2014 sampai dengan September 2019 dapat diukur dengan melihat dari laporan data sosial dan ekonomi yang diterbitkan oleh BPS. Proksi pada harga daging ayam akan diubah ke dalam satuan persentase dengan maksud untuk menyamakan satuan pada variabel gayut yang dalam bentuk persentase. Data harga komoditas daging ayam akan diubah ke dalam rumus sebagai berikut:

Harga daging ayam bulan sekarang - harga daging ayam bulan sebelumnya x $100 \%$

Harga daging ayam bulan sebelumnya

Harga cabai merah bulanan dari Oktober 2014 sampai dengan September 2019 juga dapat diukur dengan melihat dari laporan data sosial dan ekonomi yang diterbitkan oleh BPS. Data harga komoditas cabai merah akan diubah ke dalam persentase dengan rumus sebagai berikut:

Harga cabai merah bulan sekarang - harga cabai merah bulan sebelumnya x $100 \%$...

Harga cabai merah bulan sebelumnya

Penelitian ini juga akan memperoleh data harga bensin premium dari laporan data sosial dan ekonomi yang diterbitkan oleh BPS setiap bulan. Data harga komoditas bensin premium akan disamakan proksinya dengan satuan pada tingkat inflasi yaitu dalam persentase dengan diubah ke dalam rumus sebagai berikut:

Harga bensin bulan sekarang - harga bensin bulan sebelumnya x $100 \%$.

Harga bensin bulan sebelumnya

Pembahasan dengan menggunakan metode VAR-VECM akan dilakukan dengan analisis

Impulse Response Function (IRF) dan Forecast Error Variance Decomposition (FEVD). Untuk mengetahui berapa lama dan bagaimana pengaruh shock dari satu variabel terhadap variabel lain terjadi digunakan analisis IRF (Verbeek, 2017). Uji FEVD digunakan untuk mengetahui besarnya porsi pengaruh masing-masing variabel terhadap variabel gayut (Verbeek, 2017).

Uji-uji statistik lainnya harus dilakukan untuk mendapatkan model VAR-VECM terbaik. Uji stasioneritas akan menunjukkan data memiliki akar unit atau tidak (Greene, 2012). Uji selanjutnya yaitu uji (penentuan) lag optimal. Beberapa kriteria antara lain sequential modified LR test statistic (LR), Final Prediction Error (FPE), Akaike Information Criterion (AIC), Schwarz Information Criterion (SIC), dan Hannan-Quinn (HQ) digunakan dalam menentukan panjang lag yang optimal (Tarno \& Al Nisah, 2008).

Uji yang terakhir yaitu uji kointegrasi. Uji ini untuk mengetahui kemungkinan terjadinya keseimbangan atau kestabilan jangka panjang diantara variabel-variabel yang diamati walau pun pada awalnya variabel-variabel tersebut secara individual tidak stasioner, tetapi karena adanya kombinasi linier antara variabel tersebut maka dapat menjadi stasioner (Sundoro \& Theovardo, 2019). Dari hasil uji kointegrasi ini pula yang dapat menunjukkan penelitian ini lebih baik menggunakan uji VAR atau uji VECM.

Penelitian ini menggunakan model VAR-VECM karena sesuai untuk data time series dan dapat menjawab seberapa besar pengaruh setiap variabel terhadap variabel lainnya. Dalam model VAR-VECM terdapat analisis IRF dan FEVD yang dapat menjelaskan seberapa besar porsi suatu variabel dalam memengaruhi variabel lainnya di jangka pendek maupun jangka panjang (Verbeek, 2017). Model persamaan regresi dalam VAR-VECM yang dapat dituliskan dalam penelitian ini adalah sebagai berikut: 
$I N F_{t}=a 0+\sum_{i=1}^{P} a_{1} I N F_{t-i}+\sum_{i=1}^{P} a_{2}{ }_{i} G H B_{t-i}+\sum_{i=1}^{P} a_{3} G H D A_{t-i}+\sum_{i=1}^{P} a_{4}{ }_{i} G H C M_{t-i}+\sum_{i=1}^{P} a 5_{i} G H B P_{t-i}+\varepsilon_{t}$

Dimana INF adalah tingkat inflasi; $G H B$ adalah pertumbuhan harga bensin; GHDA adalah pertumbuhan harga daging ayam; dan $G H C M$ adalah pertumbuhan harga cabai merah; GHBP adalah pertumbuhan harga bensin. $a 0$ adalah vektor intersep; $a i$ adalah matriks parameter untuk setiap $i=1,2$, ... p; dan $\varepsilon$ adalah vektor sisaan. Penelitian ini menggunakan variabel-variabel harga pada komoditas pangan sebagai determinan tingkat inflasi. Alasannya adalah penelitian yang dilakukan di Serbia (Radukic et al., 2015); di Amerika Serikat (Capehart \& Richardson, 2008) dan di Indonesia (Kurniawan, 2014) menemukan bahwa inflasi dapat dipengaruhi oleh harga komoditas pangan. Fluktuasi harga bensin juga dapat menyebabkan perubahan pada tingkat inflasi sesuai yang pernah ditemukan oleh beberapa penelitian sebelumnya seperti Alvarez et al (2017) di Spanyol, Celik dan Akgul (2011) di Turki, mau pun Rangsamy (2017) di Afrika Selatan.

\section{HASIL DAN PEMBAHASAN}

Hasil uji akar unit dengan metode Augmented Dickey-Fuller (ADF) pada penelitian ini dapat dilihat pada Tabel 2. Pada tingkat level hanya variabel inflasi yang masih belum stasioner sedangkan variabel-variabel lainnya telah terbebas dari akar unit yang terlihat dengan P-value di bawah 0.05. Selanjutnya, semua data variabel akan diturunkan pada turunan pertama (first difference). Pada tingkat turunan pertama, semua data variabel penelitian telah terbebas dari akar unit.

Tabel 2.

Hasil Uji Stasioneritas

\begin{tabular}{lllll}
\hline \multirow{2}{*}{ Variabel } & \multicolumn{2}{c}{ Level } & \multicolumn{2}{c}{ First Difference } \\
\cline { 2 - 5 } & P-value & Keterangan & \multicolumn{1}{c}{$\boldsymbol{P}$-value } & Keterangan \\
\hline INF & 0,3688 & Tidak Stasioner & 0,0000 & Stasioner \\
GHB & 0,0000 & Stasioner & 0,0000 & Stasioner \\
GHDA & 0,0000 & Stasioner & 0,0000 & Stasioner \\
GHCM & 0,0000 & Stasioner & 0,0000 & Stasioner \\
GHBP & 0,0000 & Stasioner & 0,0000 & Stasioner \\
\hline
\end{tabular}

Sumber: E-views, data diolah 2020

Tabel 3.

Hasil Uji Lag Optimal

\begin{tabular}{cccllll}
\hline Lag & LogL & LR & FPE & AIC & SC & HQ \\
\hline 0 & -685.7970 & NA & 55855.57 & 25.11989 & 25.30237 & 25.19046 \\
1 & -588.1640 & 173.9642 & 3998.462 & 22.47869 & $23.57360^{*}$ & $22.90210^{*}$ \\
2 & -562.4602 & $41.12606^{*}$ & $3987.977^{*}$ & $22.45310^{*}$ & 24.46043 & 23.22935 \\
3 & -544.8841 & 24.92614 & 5542.346 & 22.72306 & 25.64282 & 23.85215 \\
4 & -528.9335 & 19.72074 & 8659.605 & 23.05213 & 26.88431 & 24.53406 \\
5 & -503.1766 & 27.16179 & 10339.36 & 23.02460 & 27.76921 & 24.85938 \\
\hline
\end{tabular}

Sumber: E-views, data diolah 2020 
Penentuan panjang lag yang akan digunakan pada penelitian ini dapat dilihat pada Tabel 3. Berdasarkan kriteria LR, FPE, dan AIC, panjang lag yang disarankan adalah lag 2. Namun sebaliknya, panjang lag 1 disarankan menurut kriteria SC dan HQ. Hasil pemilihan lag optimal ini akan dipilih model VECM dengan lag 1.

Uji kointegrasi dilakukan pada penelitian ini karena hasil uji stasioneritas menunjukkan bahwa semua data variabel telah bebas akar unit pada tingkat turunan pertama. Dengan demikian, adanya kemungkinan apakah semua data variabel di penelitian ini tetap memiliki keterkaitan dalam jangka panjang (Juanda \& Junaidi, 2012).

Tabel 4.

Hasil Uji Kointegrasi

\begin{tabular}{ccccc}
\hline $\begin{array}{c}\text { Hypothesized } \\
\text { No. of CE(s) }\end{array}$ & Eigenvalue & $\begin{array}{c}\text { Trace } \\
\text { Statistic }\end{array}$ & $\begin{array}{c}\mathbf{0 . 0 5} \\
\text { Critical Value }\end{array}$ & Prob.** \\
\hline None * & 0.784596 & 176.5628 & 69.81889 & 0.0000 \\
At most $1 *$ & 0.511713 & 87.51880 & 47.85613 & 0.0000 \\
At most 2* & 0.372262 & 45.94138 & 29.79707 & 0.0003 \\
At most 3 & 0.236612 & 18.93466 & 15.49471 & 0.0145 \\
At most 4 & 0.054906 & 3.275329 & 3.841466 & 0.0703 \\
\hline
\end{tabular}

Sumber: E-views, data diolah 2020

Hasil uji kointegrasi pada penelitian ini dapat dilihat pada Tabel 4. Adanya 4 persamaan kointegrasi yang memiliki nilai trace statistic pada taraf nyata 0,05 . Dengan demikian, adanya hubungan dalam jangka panjang antar variabel pada penelitian ini dapat terjadi. Tujuan penelitian ini dalam meramalkan pengaruh harga komoditas pangan dan harga bensin terhadap pergerakan inflasi dapat dilihat pada Gambar 2 yang merupakan hasil Impulse Response Function (IRF). Hasil IRF tersebut dapat menunjukkan bagaimana masing-masing variabel determinan dalam memengaruhi pergerakan inflasi selama masa jabatan pertama pada pemerintahan Jokowi.

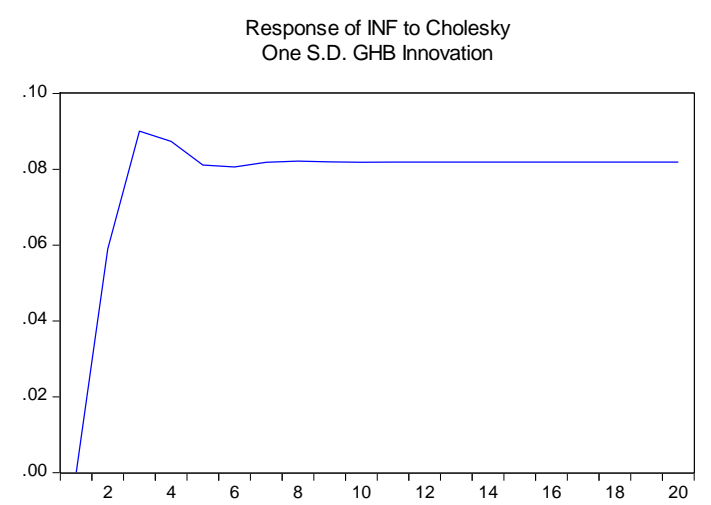

(a)

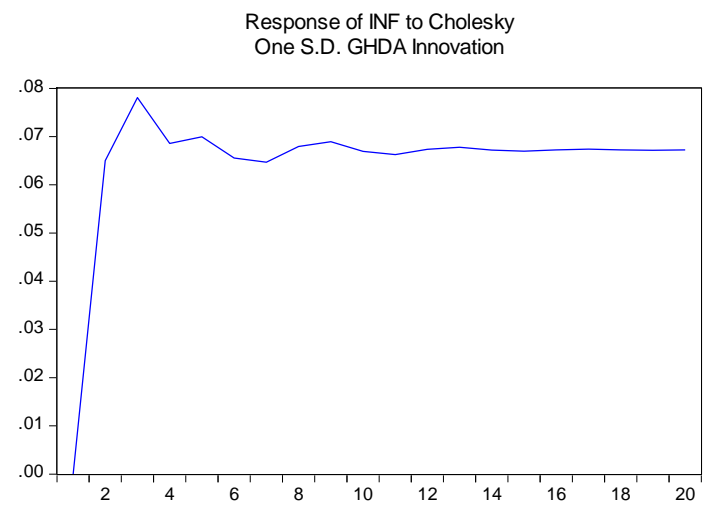

(b) 


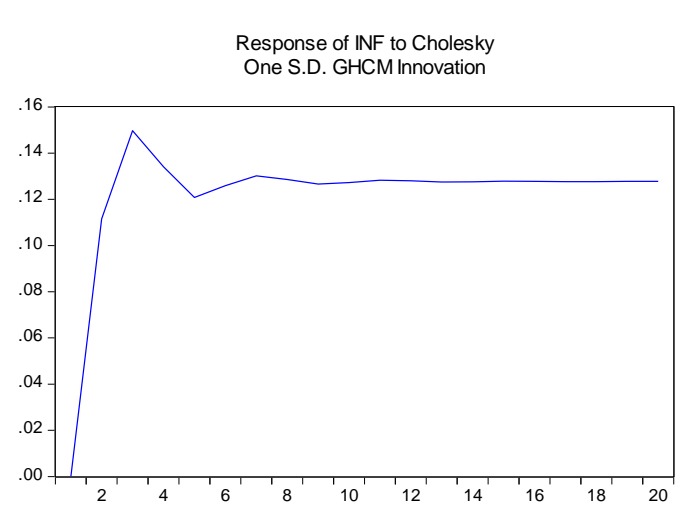

(c)

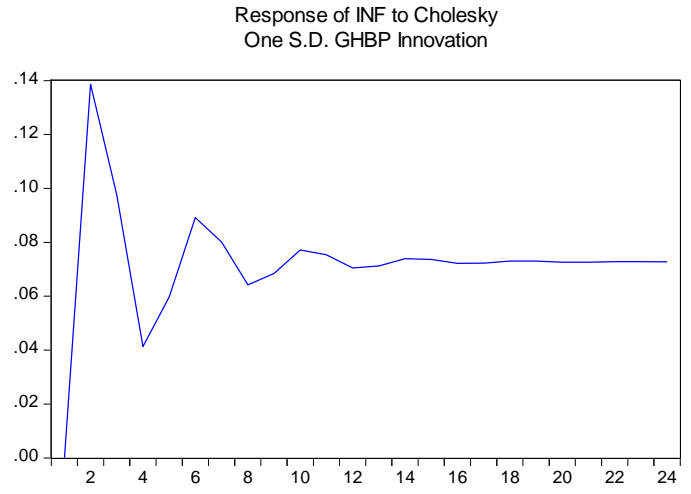

(d)

Sumber: E-views, data diolah 2020

\section{Gambar 2.}

\section{Hasil Impulse Response Function (IRF)}

Berdasarkan Gambar 2a, harga beras dapat direspon oleh inflasi secara positif selama masa pemerintahan periode pertama Presiden Jokowi. Hasil penelitian ini sesuai dengan temuan Conteh et al. (2013) di Sierra Leone, oleh Nguyen et al. (2012) di Vietnam, dan Nath (2002) di Amerika Serikat. Mereka menemukan inflasi dapat terjadi karena adanya kenaikan harga pada komoditas beras. Fenomena ini dapat menunjukkan bahwa beras yang merupakan barang inelastis dianggap sebagai kebutuhan pokok. Sehingga ketika adanya kenaikan harga beras, maka masyarakat di Indonesia tetap harus membelinya yang akhirnya hal ini akan berdampak terhadap kenaikan inflasi. Hasil penelitian ini menunjukkan ketika adanya kenaikan harga beras sebesar $1 \%$, maka inflasi juga akan turut naik sebesar $0,08 \%$.

Respon inflasi terhadap harga daging ayam yaitu positif mulai dari awal periode sampai dengan menemui kembali keseimbangan di jangka panjang seperti yang terlihat pada Gambar 2b. Hasil penelitian ini sesuai dengan temuan oleh Hayes (2012) di Meksiko. Temuannya adalah peningkatan harga ayam sebesar 22,4\% dapat menyebabkan kenaikan inflasi secara umum sebesar $0,4 \%$ di Meksiko. Penelitian ini juga menemukan hal yang sama bahwa kenaikan harga daging ayam dapat menciptakan inflasi selama masa pemerintahan Presiden Jokowi di periode pertama. Respon inflasi terhadap harga daging ayam berada di kisaran 0,067 yang artinya ketika harga daging ayam naik sebesar $1 \%$, maka inflasi akan turut naik sebesar $0,067 \%$.

Dari awal periode sampai dengan keseimbangan jangka panjang, inflasi merespon perubahan harga cabai merah secara positif seperti yang terlihat pada Gambar 2c. Respon inflasi selama periode pertama di pemerintahan Presiden Jokowi berada di kisaran 0,127 yang artinya ketika harga cabai merah naik 1\%, maka inflasi juga turut naik sekitar 0,127\%. Temuan ini sesuai dengan yang diteliti oleh Zhou \&dan Staatz (2016). Mereka meneliti pada negara-negara di kawasan Afrika Barat dan hasilnya adalah negara-negara di kawasan Afrika Barat akan mengalami peningkatan inflasi ketika harga cabai melonjak.

Dari hasil uji IRF pada Gambar 2d juga dapat menunjukkan bahwa harga bensin premium memberikan respon secara positif terhadap fluktuasi inflasi di periode pertama pemerintahan Presiden Jokowi. Penelitian sebelumnya yang pernah dilakukan oleh Alvarez et al (2017) di Spanyol, Celik \& Akgul (2011) di Turki, mau pun Rangsamy (2017) di Afrika Selatan juga meenemukan hal yang sama. Harga bensin dianggap terkait dengan biaya produksi sehingga ketika harga bensin naik, maka biaya produksi juga naik yang akhirnya harga-harga bahan pokok akan turut naik. Walaupun pada periode ke 
4 dan 5 inflasi merespon secara negatif terhadap harga bensin, namun pada periode selanjutnya sampai dengan keseimbangan jangka panjang inflasi merespon secara positif. Perubahan yang terjadi pada harga bensin dapat direspon sekitar 0.07 yang artinya ketika harga bensin naik $1 \%$, maka inflasi juga naik $0,07 \%$.

Tabel 5 dapat menunjukkan hasil Forecast Error Variance Decomposition (FEVD) untuk penelitian ini. Hasil FEVD ini dapat digunakan untuk mengetahui variabel manakah yang paling berpengaruh terhadap fluktuasi tingkat inflasi selama masa pemerintahan Presiden Jokowi di periode pertama.

Tabel 5.

Hasil Forecast Error Variance Decomposition (FEVD)

\begin{tabular}{ccccccc}
\hline Period & S.E. & INF & GHB & GHDA & GHCM & GHBP \\
\hline 1 & 0.432548 & 100.0000 & 0.000000 & 0.000000 & 0.000000 & 0.000000 \\
2 & 0.703067 & 92.66082 & 0.079579 & 1.635896 & 4.504664 & 1.119043 \\
3 & 0.873602 & 89.38143 & 0.933191 & 2.243942 & 6.661331 & 0.780102 \\
10 & 1.568280 & 88.12786 & 1.528102 & 2.483422 & 7.558213 & 0.302403 \\
11 & 1.644508 & 88.06255 & 1.549142 & 2.490891 & 7.618569 & 0.278846 \\
12 & 1.716934 & 88.02388 & 1.567340 & 2.499181 & 7.652685 & 0.256910 \\
\hline \hline
\end{tabular}

Sumber: E-views, data diolah 2020

Berdasarkan analisis FEVD pada Tabel 5 dapat diketahui bahwa variabel inflasi itu sendiri memberikan respon terbesar dengan kontribusi sebesar 100 persen pada periode awal. Pada periode jangka panjang, kontribusi inflasi cenderung menurun dan bergerak relatif konstan sebesar 88 persen. Untuk variabel GHB, GHDA, GHCM dan GHBP dalam jangka panjang hanya memberikan kontribusi secara berurutan sebesar $1,56 \% ; 2,49 \% ; 7,65 \%$; dan 0,25\%. Fluktuasi inflasi lebih dapat terjadi karena adanya perubahan dari inflasi itu sendiri, maka kebijakan moneter yang sebenarnya paling berpengaruh dalam mengendalikan tingkat inflasi.

\section{SIMPULAN DAN SARAN}

Kebijakan pengendalian harga pada komoditas pangan dan komoditas bensin harus dilakukan mengingat kedua komoditas tersebut dapat memengaruhi tingkat inflasi. Jika pemerintahan Jokowi menaikan harga pada kedua komoditas tersebut, maka tingkat inflasi pun juga akan bergerak ke arah yang sama. Namun bagaimana pun juga, kebijakan moneter yang paling efektif dalam memengaruhi tingkat inflasi selama pemerintahan Jokowi pada periode pertama.

Mengingat kedua komoditas utama tersebut dapat memberikan pengaruh secara positif terhadap tingkat inflasi, maka pemerintahan Jokowi harus dapat menekan harga di kedua komoditas tersebut. Beberapa cara yang dapat dilakukan adalah meningkatkan hasil produksi pangan sehingga harga komoditas pangan dapat ditekan. Selain itu di jangka pendek, kebijakan impor pangan atau BBM dapat dilakukan dengan tujuan untuk mencegah adanya kenaikan inflasi. Dalam hal penetapan kebijakan moneter, Pemerintah harus dapat menetapkan tingkat bunga acuan yang tidak terlalu rendah karena hal tersebut dapat mencegah penambahan jumlah uang beredar yang merupakan sebagai faktor inflasi. Pada masa pandemi seperti sekarang mungkin Pemerintah dapat menurunkan bunga acuan apalagi tingkat inflasi juga sedang rendah. Penelitian ini terbatas hanya memasukan harga komoditas sebagai variabel peubah terhadap tingkat inflasi. Pada penelitian selanjutnya dapat juga memasukkan variabel kebijakan moneter seperti tingkat bunga acuan sebagai salah satu peubah tingkat inflasi di Indonesia. 


\section{REFERENSI}

Alvarez, L. J., Sanchez, I., \& Urtasun, A. (2017). The Effect of Oil Price Fluctuations on Spanish Inflation. Banco De España, Analytical Articles.

Burhani, F. J., Fariyanti, A., \& Jahroh, S. (2013). Analisis Volatilitas Harga Daging Sapi Potong dan Daging Ayam Broiler di Indonesia. Journal IPB, 3 (2), 19-40.

Capehart, T., \& Richardson, J. (2008). Food Price Inflation: Causes and Impacts. CRS Report for Congress.

Celik, T., \& Akgul, B. (2011). Changes in Fuel Oil Prices in Turkey: An Estimation of the Inflation Effect Using VAR Analysis. Journal of Economics and Business, Volume XIV, 14 (2), 11-21.

Conteh, A. M. H., Yan, X., \& Gborie, A. V. (2013). Evaluating the Effect of Domestic Price on Rice Cultivation in an African Setting: A Typical Evidence of the Sierra Leone Case. World Academy of Science, Engineering and Technology International Journal of Economics and Management Engineering, 7 (8). $1-20$.

Greene, W. H. (2012). Econometric analysis, $7^{\text {th }}$ ed. New Jersey (US): Pearson Education.

Hayes, D. (2012). Impact of Proposed Mexican Duties on US Leg Quarters on Mexican Consumers. National Chicken Council Organization, http://nationalchickencouncil.org/wp-content/uploads/2012/05/MexicoAntidumping-ISU-Study-on-Mexican-Food-Prices.pdf.

Juanda, B., \& Junaidi. (2012). Ekonometrika Deret Waktu: Teori dan Aplikasi. Bogor: IPB Press.

Kurniawan, S, N. (2014). Analisis Faktor-Faktor yang Mempengaruhi Inflasi di Indonesia 2007-2012. Diponegoro Journal of Economics, 3 (1), 2337-3814.

Kusnadi, N. A. (2017). Pengaruh Fluktuasi Harga Komoditas Pangan terhadap Inflasi di Provinsi Jawa Timur. Jurnal Ilmiah Mahasiswa FEB-Universitas Brawijaya, 6 (2), 23-45.

Laguerodie, S., \& Vergara, F. (2008). The Theory of Price Controls: John Kenneth Galbraith's Contribution. Review of Political Economy, 20 (4), 569-593.

Nath, H. K. (2002). Relative Price Changes as Supply Shocks: Evidence from U.S. Cities. Quarterly Journal of Business and Economics, 41 (3),3-20.

Nguyen, H. M., Cavoli, T., \& Wilson, J. K. (2012). The Determinants of Inflation in Vietnam, 2001-09. ASEAN Economic Bulletin, 29 (1),1-14.

Premik, F., \& Stanislawska, E. (2017). The Impact of Inflation Expectations on Polish Consumers' Spending and Saving. NBP Working Paper, No 255.

Radukic, S., Markovic, M., \& Radovic, M. (2015). The Effect of Food Prices on Inflation in the Republic of Serbia. Journal of Central Banking Theory and Practice, 4 (2), 23-36.

Rangsamy, L. (2017). The Impact of Petrol Price Movements on South African Inflation. Journal of Energy in Southern Africa, 28 (1). 23-56.

Sundoro, H. S. (2020). Hubungan Jangka Pendek dan Jangka Panjang di antara FDI, Ekspor dan PDB. E-Jurnal Ekonomi dan Bisnis Universitas Udayana, 9 (4), 325-340.

Sundoro, H. S., \& Theovardo. (2019). Analisis Kointegrasi Pasar Modal di Indonesia dengan Pasar Modal pada Negara-Negara ASEAN selama Era MEA. AKURASI: Jurnal Riset Akuntansi Dan Keuangan, 1(2), 99110.

Tarno, D. A. I. M., \& Al Nisah, R. (2008). Uji stasioneritas data inflasi dengan Phillips - Peron test. Media Statistika, 1(1), 27-34.

Verbeek, M. (2017). A Guide to Modern Econometrics, $5^{\text {th }}$ ed. New Jersey (US): Wiley.

Zhou, Y., \& Staaz, J. (2016). Projected Demand and Supply for Various Foods in West Africa: Implications for Investments and Food Policy. Journal Food Policy, 61(2), 198-212. 